Correction - By mistake, a draft version of this paper was published in Nord. J. Bot. 20: 513-518. The correct version is published here.

\title{
A revised generic classification of the tribe Sileneae (Caryophyllaceae)
}

\author{
B. Oxelman, M. Lidén, R. K. Rabeler and M. Popp
}

Oxelman, B, Lidén, M., Rabeler, R. K. \&. Popp, M. 2001. A revised generic classification of the tribe Sileneae (Caryophyllaceae) - Nord. J. Bot. 20: 743-748. Copenhagen. ISSN-0105-055X.

\begin{abstract}
A reclassification of the tribe Sileneae compatible with molecular data is presented. The genus Eudianthe ( $E$. laeta and $E$. coeli-rosa) is restored. Viscaria, Ixoca (=Heliosperma), and Atocion together form a well supported monophyletic group distinct from Silene and Lychnis, and are recognized at generic level. With Agrostemma and Petrocoptis, the number of genera in the tribe sums up to eight. The new combinations Silene samojedora, Silene ajanensis, Lychnis abyssinica, Atocion asterias, Atocion compacta. Atocion lerchenfeldiana, and Atocion rupestris are made.
\end{abstract}

B. Oxelman, Evolutionsbiologiskt Centrum (EBC), Uppsala Universitet, Norbyvägen 18D,SE-752 36 Uppsala, Sweden.E-mail: bengt.oxelman@ebc.uu.se. - M. Lidén,, Botaniska trädgården. Uppsala universitet, Villavägen 6, SE-752 36 Uppsala, Sweden.E-mail: magnus.liden@botan.uu.se. - R. K. Rabeler, University of Michigan Herbarium, 1205 North University Ave., Ann Arbor MI 48109-1057 USA. E-mail: rabeler@umich.edu. - M. Popp. Evolutionsbiologiskt Centrum (EBC), Uppsala Universitet, Norbyvägen 18D, SE-752 36 Uppsala, Sweden. E-mail: magnus.popp@ebc.uu.se.

\section{Introduction}

With the recent advances in biotechnology, in particular the rapid development of the polymerase chain reaction (PCR) and DNA sequencing, our understanding of the phylogenetic relationships among organismal groups has improved significantly. In parallel, systematists have gradually tuned in to a paradigm, in which only putatively monophyletic groups are accepted as taxa. A consequence of all this is that numerous familiar taxonomic groups have turned out to be unacceptable. Examples are Gymnospermae (e.g. Doyle \& Donoghue 1986, but see e.g. Frohlich \& Parker 2000), Dicotyledonae (e.g. Donoghue \& Doyle 1989), and
Apocynaceae (Sennblad \& Bremer 1996). Careful analyses of molecular and/or morphological data have in all these cases revealed that at least one other taxon, traditionally recognized at the same rank, is actually an ingroup in the respective taxon (i.e. Angiospermae, Monocotyledonae and Asclepiadaceae).

Taxonomists wanting to conform both to the formal ranks in the International Code of Botanical Nomenclature (Greuter et al. 2000) and the monophyly criterion are faced with two alternatives. One could either merge all subordinate groups into a larger taxon (e.g. to put Asclepiadaceae into synonomy with Apocynaceae), or retain the subordinate groups and instead split the inclusive paraphyletic taxon into

$\overline{\text { Accepted 1-2-2001 }}$ 


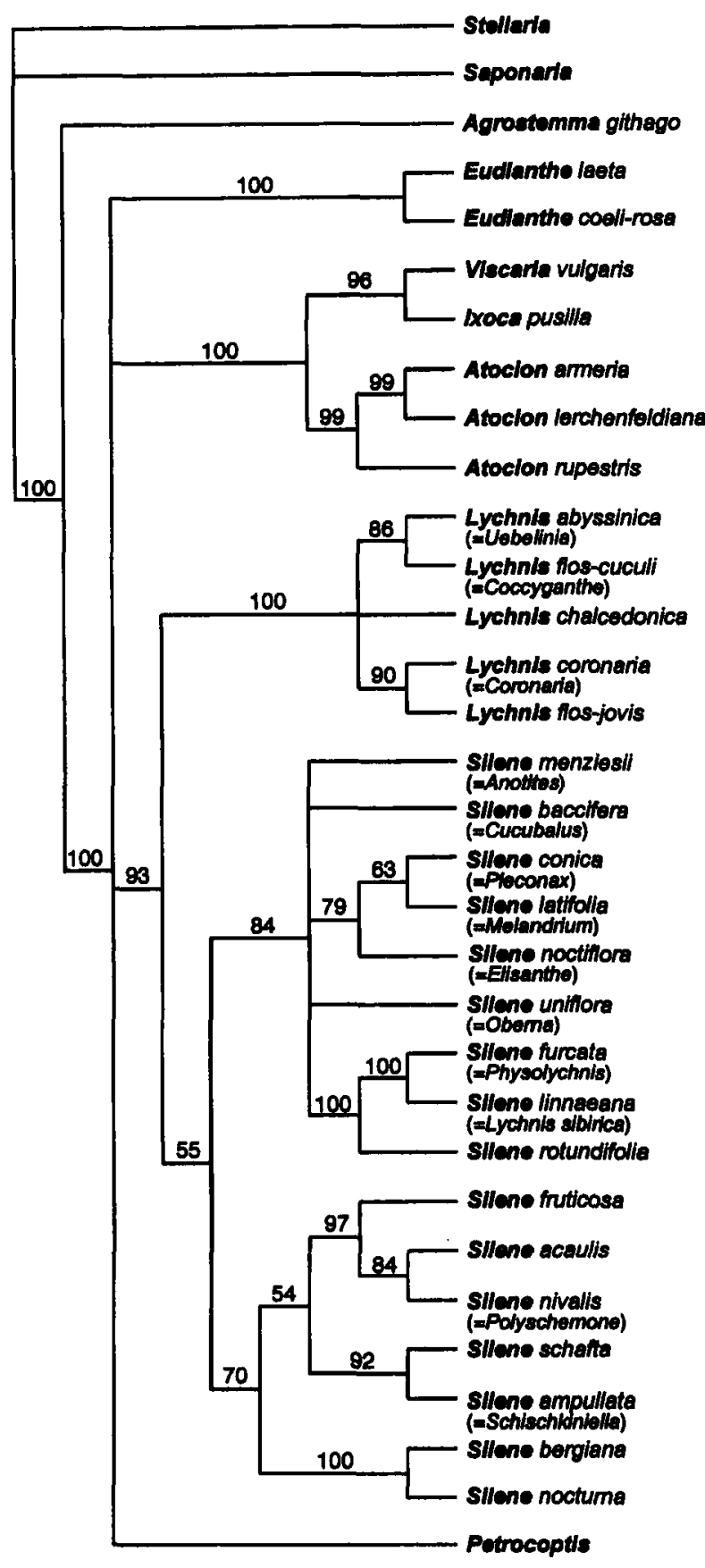

monophyletic compartments which can be recognized at the same hierarchical level.

Species names contain hierarchical information due to the binary form, in which the genus name forms the first part. Thus, information about phylogenetic relationships can be expressed directly. For example, Lidén (1986) showed that the taxon known by many horticulturists and botanists as Corydalis lutea (L.) DC. did not belong to a putatively monophyletic Corydalis DC. Therefore, the genus name Pseudofumaria Medikus was re-erected. Using the name Pseudofumaria lutea (L.) Borckh. permits the recognition of the Fumarieae (with 11 genera), which would have not been possible without violating the principle of monophyly of taxa, had it been retained in Corydalis.

However, there is a trade-off to this in terms of name stability. We see no point in inventing new names and/ or erecting old names, unless the underlying phylogenetic hypotheses are robust, and the entities are reasonably easy to recognize. Ideally, well supported and morphologically easily distinguishable components should be recognized at the generic level, promoting communication of phylogenetic results.

The tribe Sileneae has a long history of controversial taxonomy at the genus level, reviewed in e.g. Chowdhuri (1957), McNeill (1978) and Oxelman \& Lidén (1995). Here, we present a generic classification, consistent with monophyletic, diagnosable groups in Oxelman \& Lidén (1995), Desfeux \& Lejeune. (1996), and Oxelman et al. (1997). The result of a combined analysis of the nuclear ITS and plastid rps 16 intron sequences for 31 key taxa is shown in Fig.1. As is evident from that analysis, as well as from the key (below), a notable exception from the desirable criteria stated above is the genus Silene itself. In the sense advocated here it is not strongly supported, and not easily diagnosed from each of the other genera. However, the alternative to include everything except Agrostemma in the genus Silene (Greuter 1995; Mayol \& Rossello 1999) would effectively hide unambiguous hierarchical information evident from Fig. 1, because the most common way to communicate taxonomy in this group is as binomials.

Fig. $1.50 \%$ majority rule bootstrap tree based on nrDNA ITS and cpDNA rps 16 intron sequences. 1000 bootstrap replicates were generated by PAUP* version 4.0b4a (Swofford 2000), each replicate run with TBR branch swapping, multrees=on, and 5 random stepwise additions. For each replicate, the strict consensus tree was saved, and the resampling frequencies represent the proportion of replicates where the respective node was resolved. Numbers above branches indicate this resampling frequency in percent. Note that this is a more conservative approach than the one usually implemented. Details on laboratory procedures, voucher information and Genbank accession numbers are found in Oxelman \& Lidén (1995) and Oxelman \& al. (1997), except for Silene menziesii (voucher: Holmgren \& al. 2356 (UPS), Genbank accession numbers AJ409059 (ITS), and AJ409062 (rps 16)), Silene linnaeana (voucher: Gubanov 143 (GB), Genbank accession numbers AJ4090578 (ITS), and AJ409060 (rps 16 )), and Atocion lerchenfeldiana (voucher: Strid et al. no. 24188 (C) Genbank accession numbers AJ409057 (ITS), and AJ409061 (rps 16)). 


\section{Key to the genera}

1. Fruit a black pseudoberry, irregularly dehiscent ....... 1. Silene baccifera (L.) Roth

1. Fruit regularly dehiscent with teeth equal to or twice the number of styles . .2

2. Style conspicuously hairy 8. Agrostemma

2. Style glabrous . .3

3. Capsule septicidal with 3-5 teeth; style-bases reflexed and persistent in fruit . .4

3. Capsule loculicidal (usually also septicidal) with 6 or $\mathbf{1 0}$ teeth (rarely 5 teeth, but then each tooth with a distinct median line); style-bases not persistent in fruit.

4. Seeds bearded at the hilum. Aestivation imbricate ... 7. Petrocoptis

4. Seeds not bearded at the hilum. Aestivation contorted 2. Lychnis

5. Seeds with a wide marginal crest of long papillae, petals white 4. Ixoca

5. Seeds not with a crest of papillae (except in $S$. keiskei, which has pink petals) .6

6. Stigmas 5 (rarely more than 5 ) . .7

6. Stigmas 3 10

7. Flowers in a thyrsoid; bracts scarious, reddish; perennial 3. Viscaria

7. Not as above; annual or perennial .8

8. Perennial 1. Silene

8. Annual ...9

9. Leaves linear to narrowly lanceolate; flowers pink... 6. Eudianthe

9. Leaves ovate to broadly lanceolate; flowers white ... 1. Silene

10 Plant hairy 1. Silene

10. Plant glabrous 11

11. Inflorescence thyrsoidal or consisting of raceme-like monochasia 1. Silene

11 Inflorescence a regular dichasium .. 12

12 Lower leaves spathulate, different from upper leaves; petals usually lobed; calyx-veins \pm anastomosing 1. Silene

12 All leaves elliptic or oblanceolate, acute; calyx funnel-shaped with non-anastomosing veins; petals entire or emarginate . 5. Atocion

\section{Silene L.}

Linnaeus, Sp. pl.: 416 (1753) - Viscago Zinn, Cat. pl. Hort. Gott.: 188 (1757) - Kaleria Adans., Fam. pl. 2: 506 (1763) - Oncerum Dulac, Fl. Hautes-Pyrénées 255 (1867) - Corone (Hoffmanns. ex Rchb.) Fourr. Ann. Soc. Linn. Lyon. ser. 2. 16: 344. (1868) - Lectotype (vide Britton \& Brown, Ill. fl. n. U.S., ed. 2, 2: 62, 1913; Greuter, Taxon 44: 576, 1995 [typification of Viscago]): Silene anglica L. [=S. gallica L. nom. cons.].

Cucubalus L., Sp. pl. 414 (1753) - Scribaea Borkh., Rhein. Mag. Erweit. Naturk. 1: 590 (1793) - Lectotype (vide Pfeiffer, Nomencl. bot., 1871-1875: 937): Cucubalus baccifer L. (Silene baccifera (L.) Roth).

Oberna Adans., Fam. pl. 2: 255 (1763) - Behen Moench, Methodus 709 (1794), non Hill (1762) Behenantha (Otth) Schur, Verh. Naturf. Vereins Brünn 15(2): 130 (1877) - Lectotype (vide Ikonnikov, Novosti Sist. Vyssh. Rast. 13: 119, 1976): Oberna behen (L.) Ikonn. (Cucubalus behen L., Silene vulgaris (Moench) Garcke).

Otites Adans., Fam. pl. 2: 255 (1763) - Type: Otites cuneifolius Raf. (Cucubalus otites L., Silene otites (L.) Wibel).

Melandrium Röhl., Deutschl. Fl. ed. 2, 2: 37, 274 (1812) - Lectotype (vide Rabeler, Contr. Univ. Michigan Herb. 19: 161, 1993).: Melandrium sylvestre (Schkur) Röhl. (Lychnis dioica L. var. sylvestris Schkur, Silene latifolia Poir.).

Lychnis sect. Physolychnis Bentham in Royle, Ill. bot. Himal. Mts. (1839) - Physolychnis (Bentham) Rupr., Mém. Acad. Imp. Sci. Saint Pétersbourg ser. 7. 14(4): 41 (1869) - Lychnis [unranked] Gastrolychnis Fenzl in Endl., Gen. pl.: 974 (1840) - Gastrolychnis (Fenzl) Rchb., Deut. Bot. Herb.-Buch 206 (1841) Wahlbergella E. M. Fries, Bot. Not. 1843: 143 (1843) Lectotype (vide Bocquet, Phanerog. Monogr. 1: 7 , 1969): Lychnis apetala L. (Gastrolychnis uralensis Rupr., Silene uralensis (Rupr.) Bocquet).

Evactoma Raf., Aut. bot. 23 (1840) - Type: Evactoma stellata (L.) Raf. (Cucubalus stellatus L., Silene stellata (L.) Ait.).

Xamilenis Raf., Aut. bot. 24 (1840) - Type: Xamilenis uniflora Raf. nom. illeg. (Cucubalus acaulis L., Silene acaulis (L.) Jacq.).

Alifiola Raf., Aut. bot. 24 (1840) - Lectotype (vide Pennell, Bull. Torrey Bot. Club 48: 92. 1921): Alifiola dichotoma Raf. (type not seen by us).

Pleconax Raf., Aut. bot. 24 (1840) - Conosilene (Rohrb.) Fourr., Ann. Soc. Linn. Lyon ser. 2. 16: 344 (1868) - Type: Pleconax striata Raf. nom. illeg. (Silene conica L.).

Ebraxis Raf., Aut. bot. 29 (1840) - Type: Ebraxis virgata Raf. nom. illeg. (Silene antirrhina L.).

Polyschemone Schott, Nyman \& Kotschy, Analecta 
Bot. 55 (1854) - Type.: Polyschemone nivalis (Kit. ex Schult.) Schott, Nyman \& Kotschy (Lychnis nivalis Kit. ex Schult., Silene nivalis (Kit. ex Schult.) Rohrb.).

Elisanthe (Fenzl) Rchb., Deut. Bot. Herb.-Buch 206 (1841) - Type: (vide Pfeiffer, Nomencl. bot., 18711875: 1186): Elisanthe noctiflora (L.) Rupr. (Silene noctifloraL.).

Leptosilene Fourr., Ann. Soc. Linn. Lyon ser. 2. 16: 344 (1868) - Type: Leptosilene inaperta (L.) Fourr. (Silene inaperta L.).

Petrosilene Fourr., Ann. Soc. Linn. Lyon ser. 2. 16: 344 (1868) - Type: Petrosilene saxifragum (L.) Fourr. (Silene saxifraga L.).

Muscipula Fourr., Ann. Soc. Linn. Lyon ser. 2. 16: 344 (1868) - Type: Muscipula australis (L.) Fourr. (Silene muscipula L.).

Petrocoma Rupr., Mém. Acad. Imp. Sci. SaintPétersbourg ser. 7. 15(2): 200 (1869) - Type: Petrocoma hoefftiana (Fisch. \& C. A. Mey.) Rupr. (Silene hoefftiana Fisch. \& C. A. Mey.).

Anotites Greeene, Leafl. Bot. Observ. Crit. 1: 97 (1905) - Lectotype (designated here): Anotites menziesii (Hook.) Greene (Silene menziesii Hook.).

Charesia Busch, Trudy Bot. Muz. 19: 182 (1926) Type: Charesia akinfijewii (Schmalh.) Busch (Silene akinfijewii Schmalh.).

Schischkiniella Steenis, Blumea 15: 145 (1967) Gastrocalyx Schischk., Bull. Mus. Cauc. Tiflis 12: 200. (1919), non Gardner (1838) - Type: Schischkiniella ampullata (Boiss.) Steenis (Silene ampullata Boiss.).

Biennial or perennial herbs, rarely subshrubs, glabrous or pubescent. Flowers in thyrsoids, dichasia or monochasia, hermaphrodite or unisexual. Calyx with 10 or, rarely, 15-60 veins. Petal limb usually distinct from claw, entire to deeply bifid, sometimes 4-fid, auriculate or laciniate, white to pink or purple. Fruit a manyseeded capsule (rarely a pseudoberry, $S$. baccifera, or one-seded and indehiscent, $S$. ampullata), often partly divided (up to $2 / 3$ of the length of the capsule) into 3 (rarely 5) locules by thin papery septa. Capsule usually dehiscing by twice as many teeth as the number of styles. Styles 3 or 5 , their bases not persistent in fruit.

C. 650 species worldwide, most diverse in the Mediterranean, not native in Australia.

The genus Silene is in urgent need of a thorough revision. Molecular data in the form of nuclear DNA sequences (rDNA ITS regions, Oxelman \& Lidén 1995, Desfeux \& Lejeune 1996; introns of the protein gene $R P B 2$, Popp \& Oxelman in prep.), and plastid noncoding regions (rps 16 intron, Oxelman et al. 1997) conflict substantially with the most recent worldwide revision (Chowdhuri 1957).

The "Lychnis sibirica" group has hitherto been placed in Lychnis on the single criteria of 5 styles, but agrees with Silene in having capsules with loculicidal dehiscence and caducous style-bases. In the phylogenetic tree, it is firmly nested in Silene (Fig. 1). Gorschkova in Komarov (1936) recognises four species in the group. Silene ajanensis (Regel) Lidén comb. nov. (Bas.: Lychnis ajanensis Regel, Bull. Soc. Nat. Mosc. XXXIV: 564,1864 ) is quite distinct from the other three ("Lychnis" samojedorum, sibirica, and villosula) which are sometimes treated in one species. The oldest available epithets on the species level, should they be amalgamated, are samojedorum and villosula, both appearing in Komarov (1936). If all three are treated as distinct species, the correct name for "Lychnis sibirica" is Silene linnaeana V.N. Voroschilov in A.K. Skvortsov (ed.) Florist. issl. v. razn. raionakh SSR: 167 (1985). In the genus Silene, the epithet sibirica is already occupied for another unrelated species. As at least one new combination is necessary here, we formally suggest Silene samojedora (Sambuk) B. Oxelman comb. nov. (Bas.: Lychnis sibirica var. samojedorum Sambuk, Izv. Akad. Nauk SSSR VII ser. xxii: 47, 1928).

\section{Lychnis $L$.}

Linnaeus, Sp. pl.: 436 (1753) - Type: (vide Britton \& Brown, Ill. fl. n.U.S., ed. 2, 2: 68 (1913)): Lychnis chalcedonica $\mathrm{L}$.

Coronaria Guett., Hist. Acad. Roy. Sci. Mém. Math. Phys. 1750: 229 (1754) - Type: Coronaria tomentosa A. Br. (Agrostemma coronaria L.).

Hedona Lour., Fl. Cochinch.: 59, 286 (1790): - Type: Hedona sinensis Lour. (type specimen not designated; considered conspecific with Lychnis coronata Thunb. by Ohashi \& Nakai, J. Jpn. Bot. 71: 270 (1996)).

Coccyganthe (Rchb.) Rchb., Handb. nat. Pfl.-Syst. (1837) - Lychnis [unranked] Coccyganthe Rchb., Fl. germ. excurs. 825 (1832) - Type: Coccyganthe floscuculi (L.) Fourr. (Lychnis flos-cuculi L.).

Exemix Raf., Aut. bot. 27 (1840) - Type: Exemix grandiflora (Jacq.) Raf. (Lychnis grandiflora Jacq.).

Uebelinia Hochst., Flora 24: 664 (1841) - Type: Lychnis abyssinica (Hochst.) Lidén (Bas.: Uebelinia abyssinica Hochst., Flora 24: 664, 1841).

Perennial herbs, subglabrous to pubescent. Flowers in terminal, sometimes dense, dichasia (in L. flos-cuculi and $L$. subintegra with a pair of longstalked dichasia below the terminal one). Calyx with 8 or 10 veins. Petal limb vermilion, deep red, pink, purple or white, entire, bifid, 4-fid, auriculate or laciniate. Capsule unilocular, thick-walled, septicidally dehiscing by $4-5$ teeth without median lines. Styles 4-5, their bases persistent in fruit.

About 30 species, Europe, $\mathrm{C}$ and $\mathrm{E}$ Asia, $\mathrm{N}$ and $\mathrm{E}$ Africa; some are extensively cultivated as ornamentals. 
Morphology, nrDNA (Oxelman \& Lidén 1995) and cpDNA (Oxelman et al. 1997) are concordant either with recognizing Uebelinia, Coccyganthe, and Coronaria as separate genera along with Lychnis s. str, or with a more widely circumscribed Lychnis s.l., recognized by the strictly septicidal capsule and the persistent style-bases. The little known species Lychnis lagrangei (Coss.) Coss. from north Morocco belongs to the Coccyganthe/Uebelinia clade, but its exact relationship to these two taxa are not clear (Oxelman et al. 1997). Therefore we consider it appropriate with a wide circumscription of Lychnis.

\section{Viscaria Bernh.}

Bernhardi, Syst. Verz. 261 (1800), nom. cons. prop. Steris Adanson (1763), nom. rej. prop. (Oxelman et al., Taxon 50: 281, 2001) - Type: Viscaria vulgaris Bernh. (Lychnis viscaria L.).

Liponeurum Schott, Nyman \& Kotschy, Analecta Bot. 55 (1854) - Type: Viscaria alpina G. Don.

Perennial herbs with basal leaf rosettes, erect and glabrous (except for ciliate leaf-bases). Flowers in sometimes dense thyrsoids; bracts scarious. Calyx with 10 inconspicuous veins, subcylindric to campanulate. Petals entire or emarginate. Capsule thin-walled, basally 5-loculed by thin papery septa, loculicidally dehiscing by 5 teeth, each with a distinct central line, eventually often splitting into 10 teeth. Styles 5 , their bases not persistent in fruit.

Three species in Europe, one of them panarctic.

\section{Ixoca Raf.}

Rafinesque, Aut. Bot. 25. 1840 - Type: I. tenella Raf. nom. illeg. (Cucubalus quadrifidus L.).

Heliosperma Reichenbach, Deut. Bot. Herb.-Buch 206 (1841) - Silene [unranked] Heliosperma Rchb., Fl. germ. excurs. 817 (1832) - Lectotype (vide Chowdhuri 1957): Heliosperma quadrifida (L.) Griseb. (Cucubalus quadrifidus L.).

Perennial herbs, mat-forming or caespitose, pubescent. Flowers in few-flowered regular dichasia; bracts small, green with scarious margins. Calyx funnel-shaped with ten inconspicuous veins. Petals white or pink, fourlobed. Fruit a thin-walled oblong capsule dehiscing by 6 teeth. Styles 3, their bases not persistent. Seeds with prominent protuberances on the back.

Around eight species in C and SE Europe (Jalas \& Suominen 1986).

\section{Atocion Adans.}

Adanson, Fam. pl. 2: 254 (1763) - Type: Atocion armeria (L.) Raf. (Silene armeria $\mathrm{L}$.).

Annual, biennial and perennial glabrous herbs, \pm glaucous. Flowers in regular dichasia, sometimes dense. Bracts wholly scarious, or green with scarious margins. Calyx with ten inconspicuous veins. Petal limb distinct from claw, entire or emarginate; coronal scales prominent. Capsule oblong, thin-walled, dehiscing by 6 teeth, partly 3-celled by thin papery septa. Styles 3, their bases not persistent in fruit.

Five species, A. armeria (L.) Raf., Atocion asterias (Griseb.) Lidén comb. nov. (bas.: Silene asterias Griseb., spic. Fl. rumel. 1: 168, 1843), Atocion compacta (Fisch.) B. Oxelman comb. nov. (bas.: Silene compacta Fisch., Cat. Jard. Gorenki 1812:60, 1812), Atocion lerchenfeldiana (Baumg.) Popp comb. nov. (bas.: Silene lerchenfeldiana Baumg., Enum. Stirp. Transs. 1: 398, 1816), and Atocion rupestris (L.) B. Oxelman comb. nov. (bas.: Silene rupestris L. Sp. pl.: 421, 1753). Chowdhuri (1957) classified the North American species Silene menziesii Hook. and allies (=Anotites Greene) with $A$. lerchenfeldiana and $A$. rupestris in Silene sect. Rupifraga. However, DNA sequence data strongly disagrees with a close relationship to Atocion, and support a position nested in Silene (Fig. 1).

\section{Eudianthe (Rchb.) Rchb.}

Reichenbach, Deut. Bot. Herb.-Buch 206 (1841) Lychnis [unranked] Eudianthe Rchb., Fl. germ. excurs. 824 (1832) - Pontinia Fries, Bot. Not. 1843: 141 (1843). - Type: Eudianthe coeli-rosa (L.) Rchb (Agrostemma Coeli-rosa L.).

Annual erect glabrous herbs. Flowers in lax dichasia; bracts green with scarious margins. Calyx with 10 prominently raised veins. Petals entire or emarginate. Fruit a capsule, basally 5-locular by thin papery septa, dehiscing by 10 teeth. Styles 5 , their bases not persistent in fruit.

Two species in the Western Mediterranean, E. coelirosa and E. laeta Willk.

\section{Petrocoptis A. Br. ex Endl.}

Endlicher, Gen. Pl. Suppl. 2: 78 (1842) - Type: Petrocoptis pyrenaica (Bergeret) A. Br. (Lychnis pyrenaica Bergeret).

Silenopsis Willk., Bot. Zeitung 5: 237 (1847) - Type: 
Silenopsis lagascaeWillk. (Petrocoptis lagascae (Willk.) Willk.).

Perennial herbs, sometimes slightly succulent. Flowers 5-merous in few-flowered axillary dichasia; bracts leaflike. Calyx with ten inconspicuous veins. Petals with limb distinct from claw, pink, entire or emarginate; coronal scales prominent. Fruit a unilocular capsule, septicidally dehiscing by five teeth. Styles 5 , persistent in fruit. Seeds with bearded hilum.

About 4 species in the Pyrenees, see Mayol \& Rossello (1999).

\section{Agrostemma L.}

Linnaeus, Sp. pl. 435 (1753) - Githago Adans., Fam. pl. 2: 255 (1763) - Lectotype (vide Britton \& Brown, 1ll. fl. n.U.S. ed. 2. 2: 61. 1913): Agrostemma githago L.

Annual erect herbs. Flowers in lax, few-flowered dichasia; bracts leaflike. Calyx with ten conspicuously raised veins and long, leaf-like teeth. Petals, unlike other genera in the tribe, with claw not distinct from limb, and without coronal scales, pink, entire or emarginate. Fruit a uni-locular capsule, septicidally dehiscing by five teeth. Styles 5 , hairy.

Two to three species, probably native in the Mediterranean region, but widely spread as agricultural weeds.

Acknowledgements - Constructive critisism and advise from Mats Thulin and one anonymous reviewer are gratefully ackknowledged. Financial support has been obtained from the Swedish Natural Science Research Council (grant B-AA/BU 11364-304 to BO) and the Royal Academy of Science (Anna-Greta och Holger Crafoords fond to MP). We are grateful to Arne Strid for providing us with material of Atocion lerchenfeldiana, and to Dorte Boesen for patience with us.

\section{References}

Chowdhuri, P. K. 1957. Studies in the genus Silene. - Notes Roy. Bot. Gard. Edinburgh 22: 221-278.

Desfeux, C. \& Lejeune, B. 1996. Systematics of euromediterranean Silene (Caryophyllaceae): Evidence from a phylogenetic analysis using ITS sequences. $-C$. $R$. Acad. Sci. III, Vie 319: 351-358.

Doyle, J. A. \& Donoghue, M. J. 1986. Seed plant phylogeny and the origin of angiosperms: an experimental cladistic approach. - Bot. Rev. 52: 321-431.

Donoghue, M. J. \& Doyle, J. A. 1989. Phylogenetic analysis of angiosperms and the relationships of Hamamelidae. In: Crane, P. R. \& Blackmore, S. (eds), Evolution, systematics, and fossil history of the Hamamelidae. Vol. 1. Introduction and "Lower" Hamamelidae. Syst. Assoc. Special Vol. No. 40A. Pp. 17-46. Clarendon Press, Oxford.

Frohlich, M. W. \& Parker, D. S. 2000. The mostly male theory of flower evolutionary origins: from genes to fossils. - Syst. Bot. 25: 155-170.

Greuter, W. 1995. Silene (Caryophyllaceae) in Greece: a subgeneric and sectional classification. - Taxon 44: 543581 .

-, McNeill, J., Barrie, F. R., Burdet, H. M., Demoulin, V., Filgueiras, T. S., Nicholson, D. H., Silva, P. C., Skog, J. E., Trehane P., Turland, N. J. \& Hawksworth, D. L. (eds) 2000. International Code of Botanical Nomenclature (Saint Louis Code) adopted by the Sixteenth International Botanical Congress St. Louis, Missouri, July - August 1999. - Koeltz Scientific Books, Königstein.

Jalas, J. \& Suominen, J. 1986. Atlas Florae Europaeae. Vol. 7. Caryophyllaceae (Silenoideae). - Helsinki.

Lidén, M. 1986. Synopsis of Fumarioideae (Papaveraceae) with a monograph of the tribe Fumarieae. - Opera Bot. 88: 1-133.

Mayol, M. \& Rossello, J. A. 1999. A synopsis of Silene subgenus Petrocoptis (Caryophyllaceae). - Taxon 48: 471482.

McNeill, J. 1978. Silene alba and S. dioica in North America and the generic delimitation of Lychnis, Melandrium, and Silene (Caryophyllaceae). - Canad. J. Bot. 56: 297-308.

Ousted, S. 1985. A taxonomic revision of the genus Uebelinia Hochst. (Caryophyllaceae). - Bull. Jard. Bot. Natl. Belgique 55: 421-459.

Oxelman, B. \& Liden, M. 1995. Generic boundaries in the tribe Sileneae (Caryophyllaceae) as inferred from nuclear rDNA sequences. - Taxon 44: 525-542.

-, Lidén, M. \& Berglund, D. 1997. Chloroplast rps 16 intron phylogeny of the tribe Sileneae (Caryophyllaceae). - Pl. Syst. Evol. 206: 393-410.

Sennblad, B. \& Bremer, B. 1996. The familial and subfamilial relationships of Apocynaceae and Asclepiadaceae evaluated with $r b c L$ data. - Pl. Syst. Evol. 202: 153-175.

Swofford, D. L. 2000. PAUP*. Phylogenetic Analysis Using Parsimony (*and Other Methods). Version 4. - Sinauer Associates, Sunderland, Massachusetts. 